\title{
Technology and community communication: the use of radio broadcasting as a strategy for urban sustainability
}

Edney Mota Almeida [0000-0003-0494-5258], Pontifical Catholic University of São Paulo - Center for Urban Studies and Research (NEPUR), São Paulo Brazil. edneymota@yahoo.com.br

Lúcio Hanai Valeriano Viana [0000-0002-0805-6995], Observatório das Metrópoles (Metropolises Observatory) and IBMEC Group, São Paulo, Brazil. luciohanai@hotmail.com

\begin{abstract}
This work addresses a study developed in the city of São Paulo (Brazil) with the Rádio Comunitária Heliópolis (Heliópolis Community Radio Station), which from Monday to Friday, from I $2 \mathrm{~h} 00$ to $14 \mathrm{h00}$, broadcasts the programme Bairro Educador (Educating Neighbourhood). The research was conducted between November 12 and 16, 2018, aiming to understand how a community radio station can contribute to sustainable urban development. By means of participant observation, the programme schedule and episodes (via radio and the internet) and the broadcasted interviews were analysed. Despite the anthropological approach, the research was based on the theory of communication, using the concepts of social marketing and communication for development, aimed to capture changes in awareness, behaviour and human action due to the challenges imposed by contemporary society. The concepts used challenges habits and cultural and social attitudes standardized and trivialized for decades by the social structure in force. The broadcasting schedule, directed at urban sustainability, indicated strong appeal for the listeners, especially when an average of $100 \%$ increase in audience was observed the moment it was disseminated. This appeal was reaffirmed in the qualitative analysis on the listeners' participation in the social networks. These allow us to conclude that despite the difficulties in altering the population's deep-rooted behaviour standards, it is possible to envisage possibilities for social transformation using diversified communication technologies. The literature, as well as the phenomenon observed, indicates that different factors may influence actors' involvement in the search for collective solutions for common problems. It was possible to verify that a broadcast programming strategy aimed at raising awareness, mobilizing and sensitizing, placing the common citizen in the centre of the proposals, can have a significant impact in solving or reducing the problems related to urban sustainability.

Keywords - Community broadcasting station, local urban sustainability, communication technologies, community coexistence
\end{abstract}




\section{INTRODUCTION}

Heliópolis is the largest favela (slum) in the State of São Paulo, both in size and in number of inhabitants. With about 220,000 inhabitants, it is the second largest agglomeration in Brazil, after Rocinha, in Rio de Janeiro, with people forced to live in inhuman conditions, as shown by recent census data. To provide some order of magnitude, it should be noted that most Brazilian municipalities have an average of 30,000 inhabitants. This community, living in a situation of social vulnerability, faces all kinds of difficulties, but first among them is the accumulation of solid waste turned into trash. Nevertheless, some positive aspects have called our attention and serve as a reference of social engagement in the quest for solutions and relations of sustainability. Supported by the community radio, the inhabitants have been mobilized to create and cultivate green areas and to implement projects seeking income sources and economic sustainability, as is the case of Editora e Gráfica Heliópolis (Heliópolis Publisher \& Printer), founded to publish books produced by writers of the community and of the region.

In this context, the present chapter aims to demonstrate the relevance of the community radio station as a means to support initiatives and projects directed to environmental and economic sustainability as well as relations of social coexistence, in addition to highlighting the importance of broadcasting technology, by means of information and by revealing the local reality. To meet these goals, the programme 'Bairro Educador' (Educational Neighborhood) was analysed regarding the format used and the contents broadcasted. The research considered a period of one week (from Monday to Friday) covering a total of 10 hours of broadcasting. It is worth stressing that legal hurdles such as the limitation of the broadcast amplitude to 25 watts and the restriction of the height of antennas, among others, were overcome with the advent of digital technology. Actually, the internet, with the use of applications and social networks, namely Facebook, boosted the broadcasting audience significantly, multiplying the number of listeners and fostered interactivity, with visible effects on the community.

Being an instrument of communication with the target population, the community radio seems to be a relevant object of study as regards sustainable urban development. The latter understands the city as an integrated and interlinked system, linking the whole infrastructure with human well-being and the balance among living beings and the society and the environment they live in. The community radio is also differentiated since it does not consider profit or political propaganda its priorities, which allows for greater room in the broadcasting schedule dedicated to dealing with issues and topics of common interest, e.g. public, social, collective and local issues. Given its nature and vocation, the community radio can be seen as an important instrument capable of influencing, mobilizing, sensitizing, stimulating and engaging people towards social transformation, resulting in changes in behaviour for the 
benefit of sustainable urban development. Furthermore, radio has proven to be a technology capable of associating the different stages of technological advancement without forsaking its original characteristics. In this sense, the research rationale is grounded on the theory of communication and on the concepts underpinning daily actions, such as social marketing and communication for development. In this process, the community radio fulfils its role of informing, promoting debate, interviewing, rendering public interest services, educating, playing music, and is targeted at a specific audience sharing cultural, social, religious, linguistic and local affinities. According to Art. I of Law 96/2/98 (Brazilian legislation for community radio broadcast), community radio broadcast is characterised as low-power sound radio broadcast and tuned in frequency modulation. Granted by the government to foundations, communities and not-for-profit associations, community radios are forbidden from broadcasting publicity and advertisements, and are meant to be additionally targeted at local services in certain neighbourhoods and communities. Across Brazil, community broadcast stations vary, from the manner of managing their operation, to the choice of programme schedule, according to the managers' vocation and interest. In fact, the community broadcasting model differs from the private/commercial and public broadcasting radio. It has autonomy to devise its own personality and cultural identity, so as to meet the community's demands. For Peruzzo (2006), the true radio community is that which is made for and by the community. In these factors lies its fate as social and cultural equipment, able to reach the actors directly involved in the major current urban issues.

\section{THEORETICAL REFERENCES}

This research is based on the social marketing concept, according to iSMA, ESMA and AASM' (2013). The social marketing concept is far more than social media, for example, Facebook, Instagram or publicity, as it is a tool for changes in behaviour. People involved in social marketing do more than merely educate or inform. Social marketing aims to unfold and to integrate marketing concepts with other approaches to influence behaviour so as to benefit individuals and the community for greater social well-being. Social marketing practice is guided by ethical principles. Therefore, it seeks to integrate research, better practices, theory, sensitive audiences and partnership to inform and to deliver segmented programmes of social change that are effective, efficient, equitable and sustainable. According to iSMA, ESMA and AASM scholars, the pillars of social marketing are supported by mutual benefit, in a win-win situation, guided by the goal to bring about lasting changes. In this sense, its strategy involves the engagement and involvement of social actors to deliver solutions to problems. Social marketing has a great interest in people's behavioural change. Nevertheless, for this to occur, it is necessary to master some concepts and to have 
the effective participation of the people involved in the identified issues. These are usually sensitive issues and opposed to the established commercial interests. It is also characteristic of social marketing to avoid advising people on what they have to do. On the contrary, this approach seeks to motivate people towards a behavioural change, discussing the benefits in the short, medium and long terms, and stimulating daily practices that add value. An important issue is to involve people so that they realise that our behaviour impacts society whether positively or negatively, one example of which can be waste prevention. Social marketing recognizes that the change in behaviour is in fact the most complex and long-lasting way for something to occur. Moreover, it advocates that it is the most sustainable way of improving the quality of life.

The research was also inspired by the concept of communication for development (Quebral, 1988; Guglielmone, 2016; Melo, 1977). According to Quebral (1988), communication for development is the possibility for human communication science to be applied in the transformation of a nation. Communication makes a land move from poverty to a dynamic condition of economic growth, enabling greater economic and social equality and, consequently, a better quality of life. This occurs even if there is no consensus regarding the relevance of the general goal of improving the quality of life, a common source of conflicting interests. For Quebral (1988), there will always be conflict with the goals, priorities and acceptable costs, as there is a reality of constant disagreement. In this context, communication for development takes on the function of mediating conflicts since the different viewpoints of the groups of interest have to be publicly expressed. For Melo (1977), communication for development is the kind of communicative action taken for the benefit of the community. It consists of strategies aiming at social, political and economic development, among other aspects, towards social transformation, by means of communication. For Melo (1977), communication can and must be used as a tool of social organization that targets the common good. Hence, communication coupled with the concept of development towards solving conflicts and meeting social demands is an important instrument for integrating the population. In this sense, the concept of communication for development, opened to multiple aspects, can be used as a tool that allows social voices, namely those needing resonance and empowerment, to be amplified.

Guglielmone (2016) sees radio broadcasting as a tool for social development and sustainability. For her, broadcasting is usually distinguished for its capacity to reach out to populations with little or no literacy. Communication for development is thus the field of information and communication sciences in which the broadcasting mechanism is a central concept concerning the mediation processes. Still according to Guglielmone (2016), this kind of study allows us to articulate the issue of technological and production means, reception processes, the participation of the main actors and the expected actions. The author also highlights the intrinsic 
relation between development and sustainability, which can be observed in the study on the community radio of Heliópolis, the subject of this research.

\section{RESEARCH METHODOLOGY}

Between November 12 and 16 2018, we investigated the Rádio Heliópolis programme "Bairro Educador" and its Social Marketing actions to influence the change in behaviour towards community sustainability. Over the course of a week in this programme, the host Rubenildo Limeira talked to local people involved with projects and actions for sustainability in the community.

The research prioritized qualitative aspects, especially regarding the audience, observation and comprehensive description of the complex relationships between individuals and the urban environment surrounding them. To a great extent, the host made use of narratives by means of radio interviews, as a discursive way that is very close to the anthropological investigation method with the presentation of stories of life (Bauer \& Gaskell, 2013). The interviews were important with a view to exploring fully one of the characteristics of radio and its potential in the spectrum of opinions and representations of a specific social reality (Bauer \& Gaskell, 20I3). In this case, the observation of how a community radio station can use its communication potential and influence behaviour, initiatives and sustainable urban development projects. The participant observation method, also conceived as a part of the ethnographic method, was used for analysing the daily programmes, which occurred in person and systematically. The method of analysis enabled us to know more closely the characteristics of social unity present in the Heliópolis community and its relationship with the community radio of its neighbourhood (Mattos, 200 I). The programme Bairro Educador relied on debates, interviews, opinions and information that were recorded and registered in the social media. The total time of recorded materials is 10 hours, and they were selected, analysed and classified according to this research goals of demonstrating the importance of the radio station as an instrument for transforming actions towards urban sustainability. The analysis criterion was thus based on the concepts of social marketing and communication for development, having as a reference the purpose of urban sustainability. The tools for data collection, such as logbook, filming and transcriptions of the programme's sessions, helped understand the context investigated better (Gómez; Flores; Jiménez, 1996; Denzin \& Lincoln, 2000). The names of the participants and of the institutions mentioned along the sessions are real, and they gave their consent for dissemination.

\section{ANALYSIS AND DISCUSSION OF THE RESULTS}

Rádio Comunidade Heliópolis was initially called Corneta (Cornet). It started operating in 1986 and in May 1992 the station's name was changed to Rádio Heliópolis, as reported by Antonia Cleide Alves, president of Unas (União de 
Núcleos Associações dos Moradores de Heliópolis / Federation of Residents Associations of Heliópolis), responsible for the radio station. With over 26 years on air, a great number of life stories have been broadcasted and different community members have spoken into the station microphones. In the 1990s, the radio was closed three times by the Federal Police and suffered serious consequences; its electronic equipment was confiscated and the members of the board of the radio station were criminally prosecuted. This was due to the ratio not having the necessary documentation or being authorized to operate. Only on June 19, 2009 did the station receive permission by the Federal Government and started operating legally according to the Brazilian legislation on radio broadcast.

The radio has a diversified programme schedule and involves a significant number of community programme hosts, ten in total. The schedule is made by the broadcasters themselves, based on the listeners' requests. The station has programmes with interviews, debates, and different music genres, such as forró, rap, sertanejo, popular music, appealing to all the age ranges of the inhabitants. The radio broadcasts 12 hours a day. Information and news bulletins are presented throughout the programmes, as the station doesn't have a newscast. In the past, there used to be a newscast called "A Voz da Unas" (Unas' Voice). "Bairro Educador" replaced this radio programme, which currently has the largest audience of the station's programmes. "Bairro Educador" is broadcast from Monday to Friday, from I2:00 a.m. to 2:00 p.m. Rubenildo Limeira de Souza, who hosts the programme, was born in Cajazeiras, a city with just over 58.000 inhabitants in the rural area of Paraiba (Brazilian Northeast Region). According to him, Radio Heliópolis transmits what is considered important to the community.

During the week, Rubenildo plans the production of his programme. On Mondays, he invites community artists, people connected to culture; on Tuesdays the floor is reserved for the community libraries; Wednesdays are devoted to educational issues, with sessions shared with the school Centro de Educação Unificada Heliópolis, involving the participation of students and teachers; on Thursdays, schools and universities outside the community are invited to talk about their different programmes, studies and research; Fridays are reserved for the Movimento de Alfabetização de Jovens e Adultos (Movement for Young and Adult Literacy). This order is sometimes inverted, as guests change their schedules, forcing Rubenildo to make adjustments. The community writers and poets, as well as the inhabitants in general, are also invited to participate and to share their stories.

On Monday, November 12, we followed the programme and interviewed the teacher and educator Marisa Lima, from the Escola Técnica- Heliópolis (Technical School). She came to the station studios with six of her students (Jaqueline, Raissa, Bruna, Iris, Rute and Quézia) to talk about the importance of health food for health and human development at all the stages of life. The students had conducted research on the nutrition of the elderly in a senior citizens' home. Standing out among these 
experiences are the concern for and the engagement in sustainability, environmental, economic and social projects involving the production of food in its different scales. Jaqueline Ramalho, a 16-year-old girl in the second year of the nutrition programme, told radio listeners that good nutrition and good eating habits are directly related to the issue of urban sustainability. For her, as long as people have access to information and the ability to choose, they can opt for sustainably-produced and packed food. As an example, she mentioned the use of peels, such as potato and pineapple peels, which are edible and can also be used to make juice or to fertilize the land. Moreover, she stressed the importance of raising awareness of behaviour changes. Raissa Silva, a 16-year-old girl of the same class, said that nutrition does not solely concern eating. Nutrition consists in something broader, such as "feeding the soul", feeling and relating with people and with the environment. Bruna Oliveira, of the same age and a member of the group, pointed out to the listeners that she chose nutrition because she had always enjoyed cooking as a health factor. Among her concerns was the human right to healthy food. Iris Raquel related the food production cycle to the human life cycle. Rute Graziele (a 17-year-old girl) made a point of emphasizing that nutrition cannot be restricted to the act of cooking; rather, it refers above all to the health care. It is thus a gesture of love for oneself and the others. Quézia Kérin (a 16-year-old girl) articulated feeding with urban sustainability as it regards the community's health. The teacher, Marisa Lima, pointed out that the process of raising the ETEC students' awareness resulted in cultivating a community orchard within CEU Heliópolis, the community they belong to.

The analysis of the first day indicates a strong relation with the concept of social marketing advocated by the International Social Marketing Association, whose principle is directly connected to the behavioural changes that can influence large communities. Furthermore, the establishment of the community orchard, deriving from the process of dissemination and of knowledge exchange, reveals what Melo (1977) defined as communication for development. Hence, the programme of the Heliópolis community radio, as regards sustainability in food production, seems to have managed to aggregate both concepts.

On Tuesday, November 13, the programme schedule took José Genário Pereira de Araújo to the radio studio. Besides living in Heliópolis, Genário is a teacher and the director of Unas. His talk was about solid waste transformed into debris and trash, spoiling the community areas and passageways. He stated that the lack of awareness on the part of some inhabitants was causing serious problems to the community, among which visual pollution, unpleasant smells, proliferation of diseases, pollution of the ground water and of the springs found in the neighbourhood. Another serious issue pointed out by Genário was the lack of public policies for collecting discarded objects, such as old furniture, sofas, cupboards, and household appliances, such as televisions, refrigerators, washing machines. As stated by the interviewee, this was a recurring problem in the community (as well as in other peripheral areas of the 
city), usually forsaken by the government. In this sense, Genário called attention to shared responsibilities, involving the community, entrepreneurs and the government. These social drivers could provide guidelines and methods for discarding waste, often reusable. This, according to Genário, would prevent blaming exclusively the community and would also contribute to the recycling process, which, in a community as large as Heliópolis, would yield great economic and environmental benefits. Genário also made use of the radio microphone to talk about the interventions being made to minimize the negative impacts on the public space. As he said, Heliópolis relied on two water springs that were preserved by the inhabitants. It is worth pointing out that one of the water springs is used for breeding fish, which represents the awareness about the use and preservation of natural resources in a fully urbanised area. Furthermore, some areas are being revitalized; vertical orchards have been started and the project Recicla Favela ${ }^{2}$ (Recycle Favela), still not familiar to most of the inhabitants, shows different possibilities for sustainability in poor and peripheral neighbourhoods. For Genário, the government should install more recycling hotspots ${ }^{3}$ in the communities and there could be further investments in community radios so that people were made aware of the sustainability projects and, as a consequence, would be more conscious of their actions. Genário's statement corroborates the perception regarding the potential of community radios as instruments of information and raising awareness for the benefit of the community as regards the sustainability issue in its multiple facets. Genário's remarks were pertinent in a number of ways. The lack of awareness on part of the community should be highlighted. Particular importance should be given to the community radio in this issue, especially for evidencing the possibilities and problems exclusively directed to the target community. The statement made by Guglielmone (2016) seems to confirm the aim of community radios to foster social development by means of dissemination. Additionally, as public perception of social problems increases, the government tends to respond to the social demands, namely those made by voices in accord.

We should note that sustainability issues appear to be consequences of the solutions to the problems addressed. In the first situation, the solution contributed to creating the community orchard; in the second, the proposals went towards creating recycling paths. In both situations, the community radio validated the concept put forward by Guglielmone (2016) concerning the importance of social actors' participation in technological solutions, a place taken by the community radio and its resources for knowledge dissemination.

On the next day, Wednesday, we observed and helped to interview Casé de Oliveira, a biology teacher, a regional environment counsellor and an expert in composting

${ }^{2}$ Cooperative formed by the inhabitants aiming to recycle solid and organic waste.

${ }^{3}$ Places with coloured containers for solid and organic waste. 
and urban agriculture. The interviewee started his talk by reaffirming his belief in the transformation of society towards urban sustainability and, consequently, towards a healthier and more harmonious way of life. His sustainable lifestyle includes nutrition based on insects, such as maggots and crickets. According to him, including insects in human diet causes a far smaller impact on the environment. The explanation is simple and logical: insects occupy smaller spaces and, therefore, cause less damage to the environment. As stated by Casé, cattle breeding, for example, requires vast pasture areas and high water consumption. Casé also explained to the radio listeners his projects for planting seedlings all over the Heliopolis region and his environmental education actions. As a result of this work, he mapped out the degraded areas with accumulated trash, so that they could be covered with trees after being cleaned up. In total, 330 trees were planted, among them several fruit species, such as jabuticaba (Plinia cauliflora) specially chosen to attract birds. Case emphasised the indispensable support of the local population, of the Metropolitan Civil Police as well as the Department of Parks and Environment of the Municipal Government of São Paulo. The new green spaces are now frequently used by children for playing, and also by adults who seek to breathe pure air. According to Casé, the drivers that propelled the project are closely linked to the collective awareness-raising initiatives carried out at schools and in the media.

The interviewee's perception relates directly to the importance of communication for development as referred to by Quebral (1998); at is core is the application of communication sciences for social transformation. It is worth mentioning that communication, which transmits dissimilar interests, must take on the necessary interlocution concerning the disputes inherent to the democratic process. In this sense, rather than being a restricted technology, the community radio can and must be a democratic instrument. Casé's project, a clear consequence of awareness raising processes, based on information and knowledge transfer, denotes the relevance of communication for development and its impact on environmental sustainability.

On Thursday, November 15, we listened to and recorded Jorge Von's experiences. He talked about urban mobility and the negative impacts of vehicles. Jorge, having been an experienced bus driver for over two decades, is an expert on the day-to-day traffic in large cities. Aspects such as long traffic jams, noise and visual pollution, stress and deficiencies in public transport were some of the major problems highlighted. Jorge commented on the great number of private cars on the roads of large cities and pinpointed two issues. First, the still precarious and inefficient conditions of mass transport; and second, the lack of comfort in bus commuting by coupled with the feeling of inferiority of those who cannot have their own cars. However, Jorge stressed the government's concern for investing and expanding the supply of mass transport, as well as for investing in new bus corridors to improve traffic flow. After all, the use of this type of transport is more advantageous for the city in different aspects, including the reduction in polluting emissions. As measures 
to reduce traffic congestion and remove part of the cars from the roads, Jorge recalled the private car alternate-day travel strategy ${ }^{4}$ implemented in the 1990s by the Municipality of São Paulo. Another measure brought to mind and praised by Jorge was the integration system, which reduces the cost of public transport for users that need to take more than one bus or transport mode. As a further negative aspect, he highlighted the psychological pressure on public transport drivers. For him, a great number of problems could be prevented with a campaign for greater respect and appreciation for bus drivers.

Jorge's thoughts once again highlight three fundamental aspects of communication: the need for awareness-raising information, the importance of "collective thinking", and the search for sustainable solutions. To turn the latter two aspects into reality, communication for development has to provide benefits to the community. The community radio, supported by internet and social networks (i.e. Facebook), enabled a certain consensus as regards the relevance of sustainability as the ultimate goal of collective actions. These evidence the efficiency of social marketing. On the last day of observation, Friday, November 16, we followed the debate with Paulo César on economic sustainability, and then interviewed him. Paulo César was the one founders of Editora e Gráfica Heliópolis, which would be the first community publisher and printer in Brazil. Due to this innovative initiative, Paulo César and his team received a grant from Banco Itaú (a commercial bank) to start their work. On the first day of December 2018, ten writers (from the local community and the region, and some ETEC Heliópolis students) had their work published, namely short stories, prose and poetry. This peripheral literature gained an important momentum that can generate lasting change in the life of the people in the community. Paulo César, who had long dreamt of publishing a book and had not found the opportunity, collects reports of friends who were frustrated and who suffered financial and emotional losses in the attempt to have their work published by a commercial publisher. Now, besides having fulfilled a personal wish, he said that the aim of the publisher is to help other writers, poets and people like him, who wish to have their literary works printed, and this at a very affordable cost, matching that suburban reality. Another novelty presented by Paulo César concerns the paper used to print the books. A paper mill donated the material to print the first editions. A detail worth mentioning is that the paper is made from sugar cane bagasse. The production process, according to Paulo César, causes a smaller environmental impact than paper made from pulp.

The last day of participative observation was no different from the others. The interview with Paulo César once again demonstrated the importance of the community radio. The radio broadcasting technology is an instrument of information and cultural encouragement. For social marketing effects, the intrinsic relationship

\footnotetext{
${ }^{4}$ Alternate-day travel is a driving restriction used by some Brazilian cities that imposes time limits for private vehicle circulation in urban areas between 7:00 and 10:00 a.m. and between 5:00 and 8:00 p.m., based on cars' number plate.
} 
between communication and sustainable development can be verified. The significant impacts on the multiple spheres of urban sustainability inevitably involve the technological innovation of communication.

\section{CONCLUSION}

The research efforts intended to demonstrate the role of a community radio as a modern technological tool to disseminate initiatives and projects towards more sustainable urban practices, be they environmental, social or economic. The community radio provides the possibility of transforming itself and of occupying an important place in the debate about problems of public interest. At the same time, it allows the use of its microphones to amplify the voices of the social actors, legitimatizing public actions and making them more efficient.

In the observations made throughout the research, it was possible to identify the pride of the social actors and their satisfaction in disseminating initiatives and actions of public interest by means of the radio broadcasting. This behaviour inevitably evokes the concept of social marketing. Moreover, factors such as raising self-esteem and participating in the solution of problems could also be captured in the enthusiasm and in the knowledge demonstrated by the social actors during the interviews and debates conducted. A common aspect to them all is the will to help other people and to improve the reality they live in. From this perspective, the concept of communication for development can be said to be made present throughout the whole radio programming schedule. This finding is particularly important, since the community status of the radio makes it a democratic instrument, a driver of collective actions. Communication via radio is, therefore, a way of amplifying voices and of boosting experiences, in an attempt to engage and to stimulate an increasing number of people to produce changes in people's mentality and behaviour. Lastly, the social marketing strategy and the concept of communication for development applied to the local context may help with this difficult, yet necessary, task of generating positive and lasting transformations.

Throughout the week in which the research was carried out, the programme "Bairro Educador", which used to reach an average of 500 people, jumped to an average of one thousand internauts. The programme that reached the largest number of people on the Facebook page, with 2,959 listeners, was the interview with Jorge Von, who addressed urban mobility. Furthermore, the programme recording had 509 visualizations. José Genário, who discussed the solid waste issues and the problem of community trash, was heard/seen by 285 internauts via social media (Facebook). The activities recorded on the social network show the interest in sustainability themes. Moreover, the enthusiasm of the interviewed actors, as well as the expressive boost in the number of listeners, indicate a significant range of possibilities of broadcasting, now powered by new technologies, which allow for major social transformations for the benefit of the communities. 


\section{REFERENCES}

Bauer, M. W. (2013). Análise de conteúdo clássica: uma revisão. In: Bauer, M. W. \& Gaskell, G. (Eds.). Pesquisa qualitativa com texto, imagem e som: um manual prático. Petrópolis: Vozes

Denzin, N. K.; Lincoln, Y. S. (Eds.) (1998). Collecting and interpreting qualitative materials. London: Sage Publications.

Gómez, G. R.; Flores, J. G.; Jiménez, E. G. (1996). Metodologia de la investigación cualitativa. Granada: Ediciones Aljibe.

Guglielmone, I. (2016). Les Sciences du développement et la radio. In Antoine, F. (Ed.) Analiser la radio. Méthodes et mises en pratique. Louvain-la-Neuve: De Boeck Supérieur.

Lei N.O 9.612, Institui o Serviço de Radiodifusão Comunitária e dá outras providências, 19 de fevereiro de 1998.

Peruzzo, C. M. K. (2006). Rádio comunitária controvérsias, legislação e repressão. In: Marques de Melo, J., Gobbi M. C. \& Sathler, L. (Eds.). Mídia cidadã: utopia brasileira. São Paulo: Editora da Universidade Metodista.

Marques de Melo, J. (1977). Comunicação, opinião, desenvolvimento. Petrópolis: Editora Vozes.

Mattos, C. L. G. (20II). A abordagem etnográfica na investigacão científica. In Mattos, C.L.G., and Castro, P.A. (Eds.). Etnografia e educacão: conceitos e usos [online]. Campina Grande: EDUEPB, 20I I: 49-83. Available at http://books.scielo.org. Accessed on: 03/05/1016.

Quebral, N. C. (1988). Development communication. College of Agriculture, University of the Philippines at Los Banos College. Available at http://www.amazon.com/Development-communicationNora-Cruz-Quebral/dp/97III007II. Accessed on: 20/05/I016. 